\title{
Søvnproblemer blant eldre
}

\author{
Bjørn Bjorvatn ${ }^{1,2}$ og Arne Fetveit ${ }^{3}$ \\ 1) Nasjonalt kompetansetjeneste for søvnsykdommer, Haukeland universitetssykehus \\ 2) Institutt for samfunnsmedisinske fag, Universitetet $i$ Bergen \\ 3) Institutt for allmenn- og samfunnsmedisin, Universitetet $i$ Oslo \\ E-post: bjorn.bjorvatn@isf.uib.no Telefon: 55974706
}

\begin{abstract}
SAMMENDRAG
Mange eldre sover dårlig, og dårlig søvn påvirker helse og livskvalitet. Vi vil i denne artikkelen ta for oss typiske trekk ved søvnen hos eldre mennesker. Søvnsykdommer deles inn i seks ulike undergrupper: insomnier, døgnrytmeforstyrrelser, søvnrelaterte respirasjonsforstyrrelser, søvnrelaterte bevegelsesforstyrrelser, hypersomnier og parasomnier. Hovedfokuset i artikkelen vil være på insomni, men også de andre søvnsykdommene blir beskrevet. Flere av søvnsykdommene er hyppigere hos eldre enn hos yngre mennesker. I tillegg er mange somatiske og psykiske lidelser assosiert til søvnproblemer, hvorav depresjon regnes som den hyppigste komorbide lidelsen. Grundig anamnese vil avdekke de fleste av søvnsykdommene, og bruk av søvndagbøker gir viktig tilleggsinformasjon. Behandlingsalternativene varierer fra ikke-medikamentelle til medikamentelle tiltak, avhengig av hvilken diagnose som stilles. Langvarig bruk av hypnotika frarådes på grunn av toleranseutvikling og uheldige bivirkninger. Det er viktig at utredning gjøres før behandlingen starter, og korrekt behandling kan ha stor effekt - også hos eldre.
\end{abstract}

Bjorvatn B, Fetveit A. Sleep problems among the elderly. Nor J Epidemiol 2012; 22 (2): 177-186.

\section{ENGLISH SUMMARY}

Sleep problems are common among the elderly, and poor sleep affects health and quality of life. In this paper we will cover the characteristics of sleep in elderly patients. Sleep disorders are divided into six subgroups: insomnia, circadian rhythm sleep disorders, sleep related breathing disorders, sleep related movement disorders, hypersomnias, and parasomnias. The main focus of this paper will be on insomnia, but also the other sleep disorders will be described. Several of the sleep disorders are more common among older than younger people. Furthermore, many somatic and psychiatric disorders are associated with sleep problems, with depression being the most common comorbid disorder. A thorough patient history will uncover most of the sleep disorders, and the use of sleep diaries gives important additional information. The treatments of choice vary from non-pharmacological to pharmacological approaches, depending on the diagnosis. Chronic use of hypnotics is discouraged due to risk of tolerance and unfavourable side effects. It is vital to do a proper assessment before treatment is commenced, and appropriate treatment may have large effects - also among elderly patients.

\section{INTRODUKSJON}

Helse og velvære er avhengig av god søvn. De fleste av oss har opplevd en natt med dårlig søvn, og vet hvordan det påvirker humøret, konsentrasjonen og yteevnen. Søvnproblemer og søvnighet er vanlige årsaker til ulykker, for eksempel i trafikken. Norske studier har dokumentert at dårlig søvn gir økt sykefravær og uføretrygd. Behovet for søvn er imidlertid veldig varierende fra person til person. Enkelte mennesker klarer seg med få timer, kanskje færre enn 6 timer, mens andre trenger over 9 timer søvn for å fungere normalt. Flertallet (over 90\%) rapporterer en søvnlengde mellom 6 og 9 timer. Slik variasjon i søvnlengden betyr at det er viktig ikke å vurdere en pasients søvn kun utfra hvor mange timer han eller hun sover. Kvaliteten på søvnen, det vil si mengden av den dype søvnen, er vel så viktig som antall timer. Som hovedregel gjelder at hvis man er uthvilt på dagtid, har man fått tilstrekkelig med søvn, uavhengig av antall timer. I denne artikkelen vil vi først beskrive normal søvn og søvnregule- ring, og deretter fokusere på typiske trekk ved søvnen hos eldre. Hoveddelen av artikkelen omhandler forekomst, utredning og behandling av de ulike søvnsyk dommene.

\section{NORMAL SøVN}

Kvaliteten på søvnen varierer betraktelig gjennom natten (figur 1). Grovt sett deles søvnen inn i to hovedstadier (1). Det ene stadiet kalles REM-søvn, hvor man blant annet observerer karakteristiske hurtige øyebevegelser (Rapid Eye Movements) og muskelatoni. Det andre stadiet kalles NREM-søvn (Non Rapid Eye Movements). NREM-søvn utgjør det meste av søvnen vår, rundt $75-80 \%$. Både puls og blodtrykk reduseres $\mathrm{i}$ NREM i forhold til våkenhet, og respirasjonen blir dypere og langsommere. NREM-søvn deles videre inn i lette og dype understadier. Det er spesielt den dype NREM-søvnen (deltasøvnen) som er viktig for å bli uthvilt og fungere bra neste dag. Denne søvnen sees de første 3-4 timene av søvnperioden (figur 1), uavhengig 


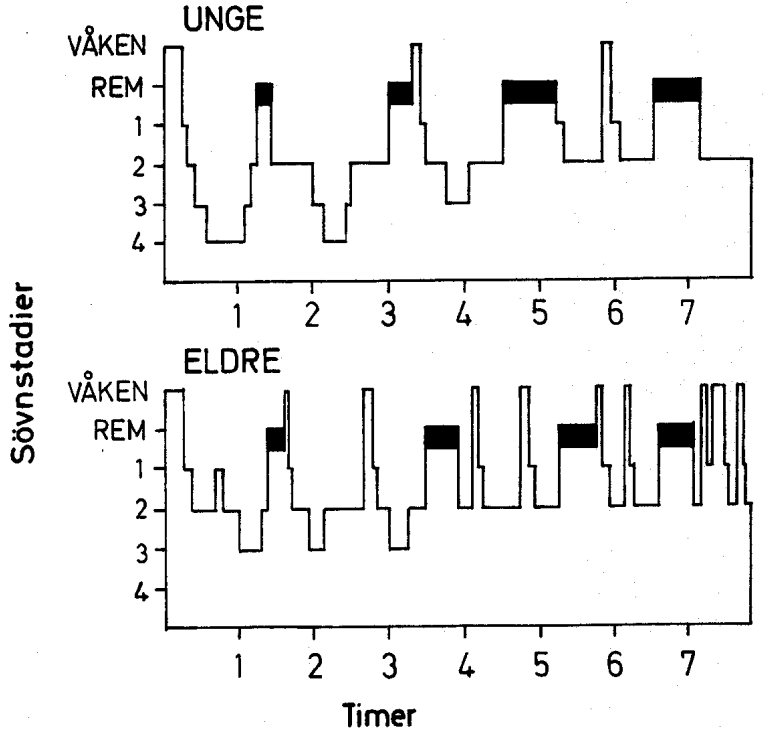

Figur 1. Fordeling av de ulike søvnstadiene hos unge og eldre (figuren er hentet fra bokkapittelet "Søvnforstyrrelser hos eldre" av Bjørn Bjorvatn og Arne Fetveit i boken "Aldring og hjernesykdommer", Akribe forlag, 2003).

av sengetid. REM-søvn skiller seg markert fra NREMsøvn. I REM-søvn er hjernebølgene nesten som under våkenhet, samtidig som den viljestyrte muskulaturen er i sin mest avslappete fase. Drømming er vanlig i REM-søvn, men man kan også drømme i NREM-søvn. Puls og blodtrykk varierer under REM-søvn. Med tanke på funksjonsnivået neste dag regnes REM-søvn som lite betydningsfull i forhold til den dype deltasøvnen.

\section{SøVNREGULERING}

Søvnlengden og søvndybden reguleres i hovedsak av et samspill mellom tre faktorer: Homeostatisk faktor, cirkadian faktor og vaner/atferdsfaktorer (1). Det er døgnrytmen (cirkadian faktor) som i hovedsak bestemmer hvor mange timer man sover, og hvor trett man er når man legger seg. Dette betyr at søvnlengden varierer betydelig etter når på døgnet man legger seg, nesten uavhengig av hvor lenge man har vært våken. Antall timer $i$ våken tilstand bestemmer imidlertid søvndybden. Homeostatisk faktor bygger seg opp mens man er våken, og søvnen blir dypere (mer langsomme deltabølger) jo lenger det er siden man sov sist. Samspillet mellom den homeostatiske og cirkadiane faktoren er derfor vesentlig for normal søvn, og denne forståelsen benyttes i moderne behandling av søvnproblemer. $\mathrm{Va}$ ner og atferdsfaktorer regulerer også hvordan og når man sover. Sengetiden er ikke nødvendigvis i overensstemmelse med når man er trett. Mange er mindre trette om kvelden enn tidligere på dagen, som for eksempel sent på ettermiddagen. Likevel legger de fleste seg stort sett til samme tid hver kveld, fordi man vet at man trenger et visst antall timer med søvn for å fungere neste dag. Søvnen er veldig avhengig av slike faste vaner. Atferdsfaktorer gjør at for eksempel nattarbeidere klarer å holde seg våken om natten. Midt på natten tilsier både den homeostatiske og den cirkadiane faktoren at han eller hun burde sove. Likevel klarer nattarbeideren å holde seg våken, ved hjelp av ulike atferdsfaktorer, som for eksempel inntak av koffein, bevegelse, samtale med andre etc. Atferdsfaktorer, eller mangel på slike, kan også forklare at enkelte sovner under en kjedelig forelesning i et mørkt rom klokken ni om formiddagen, selv om både den homeostatiske og den cirkadiane faktoren tilsier at det burde være lett å holde seg våken. Redusert stimulering av hjernen, og dermed redusert aktivering, forklarer den uimotståelige trettheten i slike sammenhenger.

\section{GENERELT OM SøVNEN HOS ELDRE}

Søvnen endres med årene, og forekomsten av de ulike søvnsykdommene varierer også avhengig av alder. Søvnen hos eldre kjennetegnes i hovedsak av at det blir det vanskeligere å sove sammenhengende gjennom natten, og samtidig er mange eldre trette om dagen (2). Mange eldre mennesker sover i korte eller lengre perioder på dagtid, noe som er mer uvanlig i ung alder. Om lag halvparten av alle personer over 65 år rapporterer søvnplager. Undersøkelser blant eldre viser at disse plagene er assosiert med følelse av nedsatt livskvalitet, psykiske plager og begrensninger i daglige gjøremål (2). Belastningen som søvnproblemene fører med seg for pasient og pårørende er ofte den utløsende årsaken til at pasienten innlegges på sykehjem. Langt fra alle eldre med søvnplager mottar adekvat behandling (3). Dette kan skyldes at den eldre personen ikke oppsøker hjelp for sitt problem fordi søvnvansker oppfattes som en del av normal aldring, eller at helsepersonell ikke i tilstrekkelig grad kjenner de ulike behandlingsalternativene.

Årsaken til det endrede søvnmønsteret hos eldre kan delvis skyldes en sviktende funksjon i døgnrytmesenteret i hjernen, det vil si en dysfunksjon i nucleus suprachiasmaticus $(2,4)$. En vanlig endring i søvnmønsteret med økende alder er at døgnrytmen fremskyndes, slik at man kjenner seg tidligere trett om kvelden og våkner tidligere om morgenen. Man blir med andre ord mer A-menneske jo eldre man blir. Videre ser det ut til at amplituden på døgnrytmen får mindre utslag, slik at forskjellen på natt og dag blir mindre. Dette forklarer $ø k t$ søvntrang på dagtid. En annen viktig biologisk endring med årene er at mengden av den dype søvnen reduseres (5). Ved høy alder kan dyp søvn være helt forsvunnet. REM-søvn er mindre affisert. Dette betyr at søvnen blir mer overfladisk, og av dårligere kvalitet. Dette forklarer hvorfor eldre har flere oppvåkninger om natten (se figur 1). Forandringene i søvnmønsteret hos demente og ikke-demente eldre har samme karakter, men alvorlighetsgraden er generelt høyere hos demente. Det har vært en vanlig oppfatning at eldre trenger mindre søvn enn unge. Dette er imidlertid omdiskutert. Flere undersøkelser viser at søvnbehovet og søvnlengden er relativ lik gjennom hele vårt voksne liv, men at søvnen hos eldre fordeles ut over flere av døgnets timer. 
Eldre mennesker som bor hjemme sover generelt sett bedre enn eldre pasienter på sykehjem eller sykehus. Dette kan naturlig nok skyldes mange forhold. En amerikansk undersøkelse viste at mange sykehjemspasienter verken sov eller var våkne $i$ en hel time av gangen, i løpet av døgnets 24 timer (6). I en norsk studie fant vi at prevalensen av søvnforstyrrelser blant sykehjemspasienter var 72\% (7). Personer med demens har ofte særlig alvorlige søvnplager. Sykehjem er ofte dårlig tilrettelagt for søvn (8). Nattlige pleierutiner, delte rom, alarmer, høylydte TV- og radioapparater og annen støy kan lett forstyrre søvnen. Også dagtidsrutiner kan påvirke søvnkvaliteten. Mange sykehjem har få eller lite stimulerende aktiviteter på dagtid, og heller ikke tilbud om regelmessig fysisk aktivitet. Ofte henvises pasientene til lange perioder preget av inaktivitet og kjedsommelighet. Hvis pasienten faller i søvn om dagen, reduseres den homeostatiske faktoren og nattesøvnen forringes. Den cirkadiane rytmen er også avhengig av stimulering som signaliserer dagtid. Av slik stimulering er lys det viktigste, men også fysisk aktivitet, måltider og sosial interaksjon spiller en rolle.

\section{SøVNSYKDOMMER}

Søvnproblemer kan skyldes en rekke forskjellige faktorer. Det er derfor viktig at pasienter som lider av dårlig søvn gjennomgår en grundig utredning, uavhengig av alder. Faktorer som utløser søvnproblemer kan for eksempel være kritiske hendelser og belastninger i personens liv, eller psykiske og somatiske sykdommer. De faktorene som bidrar til å opprettholde et søvnproblem, er ikke nødvendigvis de samme som utløste problemet. Hvis utredningen avdekker en sannsynlig bakenforliggende årsak til søvnproblemene kan behandlingen i første omgang rettes mot denne årsaken. Men ofte kan søvnproblemene vedvare etter at den bakenforliggende årsaken er behandlet. Spesifikk søvnbehandling er derfor ofte nødvendig. Hos eldre er det vanligere med komorbiditet enn hos yngre, det vil si at mange eldre har psykiske eller fysiske lidelser som kan være med å forklare eller forverre søvnproblemene.

Søvnforstyrrelser hos eldre har en rekke negative konsekvenser. Dette gjelder særlig økt risiko for å utvikle psykiske lidelser, redusert kognitiv funksjon, hukommelsesproblemer og mestringsproblemer (2).

Søvnforstyrrelser deles inn i seks hovedkategorier: Insomnier, døgnrytmeforstyrrelser, søvnrelaterte respirasjonsforstyrrelser, søvnrelaterte bevegelsesforstyrrelser, hypersomnier og parasomnier. Vi vil her belyse disse søvnsykdommene med hovedfokus på insomni.

\section{INSOMNI}

Insomni regnes som den vanligste søvnlidelsen, og er definert som subjektivt dårlig søvn enten på grunn av innsovningsvansker, urolig nattesøvn, for tidlig oppvåkning om morgenen, eller redusert kvalitet på søvnen (9). I tillegg må disse søvnendringene føre til nedsatt funksjon på dagtid for at diagnosen kan stilles. Forekomsten av diagnosen insomni øker med økende alder, fra rundt $10 \%$ i ung voksen alder til $20-30 \%$ hos eldre (10). Kvinner er langt hyppigere rammet enn menn, men kjønnsforskjellen er først tydelig fra rundt 45 års alder (10).

Insomni har tradisjonelt blitt klassifisert som enten primær (ukjent årsak) eller sekundær (kjent årsak). Ved insomni forårsaket av for eksempel depresjon, ble behandlingen rettet mot depresjonen og det ble forventet at de ledsagende søvnproblemene skulle opphøre når depresjonen var vellykket behandlet. I den senere tid har imidlertid insomni blitt anerkjent som en selvstendig sykdom, og det anbefales å bruke begrepet komorbid insomni framfor sekundær insomni (11). Hvis en pasient har både insomni og depresjon anbefales det å behandle begge tilstandene samtidig (11).

Vanlige komorbide psykiske og fysiske lidelser hos eldre er angst, depresjon, demens, hjerneslag, stoffskiftesykdom, smerter (for eksempel fra slitasjegikt), nokturi og hjerte-lungesykdommer. I tillegg kan en rekke medikamenter forstyrre søvnen. Og bruk av mange medisiner samtidig (polyfarmasi) er vanlig hos eldre. Blant de legemidler som særlig relateres til søvnforstyrrelser er betablokkere, bronkodilatatorer, kalsiumblokkere, diuretika, kortikosteroider, thyroxin og selektive serotonin-reopptakshemmere.

En grundig anamnese vil avdekke mulige årsaker til søvnproblemene hos den eldre pasienten. Føring av søvndagbok (tabell 1) i 1-2 uker gir også mye nyttig og viktig informasjon. Validerte spørreskjemaer og søvndagbok kan lastes ned fra hjemmesidene til Nasjonal kompetansetjeneste for søvnsykdommer (www.sovno.no).

De fleste pasienter, ikke minst de eldre, med kronisk insomni blir i dag behandlet med medikamenter, til tross for at hypnotika kun har indikasjonen kortvarige eller forbigående søvnvansker. Ved akutte søvnplager regnes hypnotika som en trygg og god behandling, med få bivirkninger (12). Langvarig bruk bør imidlertid unngås av flere grunner. Den viktigste grunnen er at effekten av hypnotika vanligvis taper seg raskt, og etter noen ukers bruk ser effekten på søvn ut til å være liten $(13,14)$. Hypnotika er kjent for å kunne gi avhengighet, og ha et misbrukspotensial (13). Til tross for dette bruker mange pasienter hypnotika i årevis, angivelig med en viss subjektiv effekt (15). Mer forskning er nødvendig for å undersøke om noen pasienter kan ha nytte av slik langtidsbehandling, og hvilke farer som finnes rundt slik bruk. En stor amerikansk undersøkelse viser at brukere av benzodiazepiner har signifikant økt mortalitet sammenliknet med ikke-brukere, selv etter korrigering for en lang rekke andre mortalitetsrelaterte faktorer (16). Det er viktig å understreke at det finnes annen type behandling enn medikamenter, og at slik behandling har effekt og bivirkninger som er klart mer fordelaktige enn hypnotika. Slik behandling går gjerne under navnet ikke-medikamentell søvnbehandling. 
Tabell 1. Søvndagbok (C Bjørn Bjorvatn).

Navn:

Spørsmål 1 og 2 fylles ut før sengetid, resten av skjemaet fylles ut om morgenen. Husk å notere dato.

\begin{tabular}{|c|c|c|c|c|c|c|c|c|}
\hline & $\begin{array}{c}\text { Eksempel } \\
01.11 .12\end{array}$ & $\begin{array}{c}\text { Man- } \\
\text { Tirs }\end{array}$ & $\begin{array}{l}\text { Tirs- } \\
\text { Ons }\end{array}$ & $\begin{array}{l}\text { Ons- } \\
\text { Tors }\end{array}$ & $\begin{array}{l}\text { Tors- } \\
\text { Fre }\end{array}$ & $\begin{array}{l}\text { Fre- } \\
\text { Lør }\end{array}$ & $\begin{array}{l}\text { Lør- } \\
\text { Søn }\end{array}$ & $\begin{array}{l}\text { Søn- } \\
\text { Man }\end{array}$ \\
\hline $\begin{array}{l}\text { 1. Hvordan har du fungert på dagtid? } 1=\text { veldig bra, } 2= \\
\text { bra, } 3=\text { middels, } 4=\text { dårlig, } 5=\text { veldig dårlig. }\end{array}$ & 4 & & & & & & & \\
\hline $\begin{array}{l}\text { 2. Har du tatt en eller flere blunder i løpet av dagen? Notér } \\
\text { tidspunktene for alle blundene. }\end{array}$ & $\begin{array}{l}16-16.30 \mathrm{og} \\
18.15-18.30\end{array}$ & & & & & & & \\
\hline $\begin{array}{l}\text { 3. Har du tatt sovemedisin og/eller alkohol som hjelp til å } \\
\text { sove? Notér medikament og dose, samt evt alkoholinntak. }\end{array}$ & $\begin{array}{l}5 \mathrm{mg} \text { Imovane } \\
1 \text { glass rødvin }\end{array}$ & & & & & & & \\
\hline $\begin{array}{l}\text { 4. Når gikk du til sengs? } \\
\text { Når skrudde du av lyset? }\end{array}$ & $\begin{array}{l}22.30 \\
23.00\end{array}$ & & & & & & & \\
\hline 5. Hvor lang tid tok det fra lyset var skrudd av til du sovnet? & $45 \mathrm{~min}$ & & & & & & & \\
\hline 6. Hvor mange ganger våknet du i løpet av natten? & 3 & & & & & & & \\
\hline $\begin{array}{l}\text { 7. Hvor lange var oppvåkningsperiodene (oppgi antall } \\
\text { minutter for hver oppvåkning)? }\end{array}$ & $15,30,80$ & & & & & & & \\
\hline $\begin{array}{l}\text { 8. Når våknet du opp om morgenen uten å få sove igjen? } \\
\text { Notér tidspunktet for din endelige oppvåkning. }\end{array}$ & 06.15 & & & & & & & \\
\hline 9. Når stod du opp? & 06.40 & & & & & & & \\
\hline $\begin{array}{l}\text { 10. Hvordan var siste natts søvn totalt sett: } 1=\text { veldig lett, } \\
2=\text { lett, } 3=\text { middels, } 4=\text { dyp, } 5=\text { veldig dyp. }\end{array}$ & 1 & & & & & & & \\
\hline
\end{tabular}

Ikke-medikamentell søvnbehandling består av ulike komponenter (17), hvor stimuluskontroll og søvnrestriksjon har best dokumentert effekt (18). Kognitive teknikker, avspenningsøvelser og søvnhygiene (tabell 2) inngår ofte i behandlingspakken. Kognitiv atferdsterapi for insomni (CBTi) er fellesbetegnelsen på denne type behandling. Kort beskrevet går stimuluskontrollbehandling ut på å korrigere uheldig søvnatferd, og å styrke assosiasjonen mellom søvn og seng. Pasienten får et sett med instruksjoner som skal følges nøyaktig. Det understrekes at sengen kun skal brukes til å sove i. Får man ikke sove, skal man stå opp, gå ut av soverommet og ikke returnere til sengen før man igjen er søvnig. Tidspunktet for å stå opp om morgenen er bestemt på forhånd, og skal ikke justeres etter hvor mye søvn pasienten reelt får hver natt. Det er ikke tillatt å sove på dagtid. Mange pasienter med dårlig søvn kompenserer med å tilbringe lang tid i sengen, i håp om å få sove, og iallfall få noe hvile. Det er ganske vanlig at pasienter med rundt fem timers nattesøvn ligger i sengen i 9-10 timer. Dette gjør sengen og soverommet til et sted for frustrasjon, noe som i neste omgang kan forklare hvorfor søvnvanskene opprettholdes. Søvnrestriksjon tar sikte på å redusere tiden i sengen til den tiden pasienten reelt sover. Søvndagbøker benyttes til å
Tabell 2. Søvnhygieneråd.

Råd for å ta vare på oppbygget søvnbehov

- regelmessig mosjon, avslutt minst $3 \mathrm{t}$ før sengetid

- unngå søvn om dagen (evt middagslur $<20$ min)

- ikke opphold deg i sengen lenger enn forventet sovetid

Råd for å bevare god døgnrytme

- stå opp til omtrent samme tid hver dag, også i helger

- få minst $1 / 2$ time med dagslys daglig, helst tidlig om morgenen (innen $2 \mathrm{t}$ etter at du har stått opp)

- unngå sterkt lys dersom du må opp om natten

Råd for å redusere aktivering om kvelden og natten

- unngå kaffe, te og cola etter kl. 17, stump røyken

- unngå kraftig mosjon siste timer før sengetid

- unngå å være sulten/innta tungt måltid ved sengetid

- bruk soverommet til å sove i, ikke til arbeid

- lag deg et sengetidsrituale

- sørg for mørke, ro og moderat temperatur på soverommet, bruk evt maske og øreplugger

- ikke se på klokka hvis du våkner om natten

- lær deg en avspenningsteknikk, bruk den ved oppvåkninger

- sett av tid til konfliktløsning ("problemtime") om ettermiddagen/tidlig kveld

- ta et varmt bad et par timer før sengetid

Unngå regelmessig bruk av sovemedisiner og alkohol 
regne ut søvnlengden. Tiden pasienten får oppholde seg i sengen justeres fra konsultasjon til konsultasjon basert på endringer i søvneffektiviteten (total søvnlengde dividert på tid i sengen). Er søvneffektiviteten over $80-85 \%$, økes tid i sengen med 15 minutter, hvis ikke, fortsetter pasienten vanligvis uendret. Tid i sengen anbefales aldri redusert til under fem timer. Denne type atferdsterapi krever en motivert pasient som klarer å følge instruksjonene. Behandlingen er krevende, og ofte sees en forverring av søvnplagene de første 1-2 ukene før bedring inntrer. Det er viktig å forberede pasienten på dette. Kognitive teknikker handler om å identifisere dysfunksjonelle forestillinger og kognisjoner som kan bidra til å opprettholde søvnvanskene. Målet med kognitiv terapi ved insomni er å korrigere disse dysfunksjonelle forestillinger og kognisjoner.

Behandling av insomni hos eldre følger samme retningslinjer som hos yngre pasienter. CBTi har veldokumentert effekt hos eldre, og kan med hell også benyttes hvis pasienten har komorbide lidelser som påvirker søvnen, for eksempel depresjon eller smerter. I klinisk praksis støter vi av og til på eldre pasienter som ikke er veldig motivert for CBTi, men i stedet ønsker medikamentell behandling. Slike pasienter kan være utfordrende. Studier viser at pasienter med kronisk insomni ofte har dårlig effekt av langvarig bruk av sovemedisiner. I tillegg har slike medikamenter gjerne bivirkninger, som kan være mer uttalte hos eldre enn yngre pasienter. For eksempel gir ofte sovemedisiner hangover, kognitive problemer og redusert gangfunksjon. Slike momenter bør diskuteres med pasienten. En forenklet CBTi kan ofte være lettere å få til hos en skeptisk eldre pasient. Vi vil da spesielt anbefale søvnrestriksjon, det vil si at pasienten anbefales å begrense tiden som tilbringes i sengen. Pasienten bør først gå til sengs når han eller hun er blitt ordentlig søvnig. Enkelte eldre legger seg tidlig om kvelden, før søvnbehovet er tilstrekkelig oppbygget.

Blant sykehjemsbeboere kan ulike miljøtiltak være viktige for å bedre søvnen (8). Flere undersøkelser viser at uheldige pleierutiner kan forstyrre søvnen. Lys, lyd og forstyrrelser fra andre pasienter på rommet peker seg ut som de mest ødeleggende miljøfaktorene for søvn. Forbedrende tiltak kan være å lukke dører, skru ned lyd på TV-apparater og radio etter kl 21, skru av TV-apparater som ingen ser på, sørge for enkeltrom til de som ønsker det, og å bruke minimalt med lys (lommelykt) ved nattlige pleierutiner. Individuelle faktorer som bedrer søvnen kan være å gi adekvat smertelindring, planlegge inkontinenspleie slik at det $\mathrm{i}$ minst mulig grad fører til oppvåkninger og å ha faste kveldsrutiner som pasienten forbinder med søvn. Sykehjemmets nattskift har et særlig ansvar for å identifisere forstyrrende miljøfaktorer og å foreslå nødvendige tiltak.

\section{Medikamentell behandling}

Det finnes to hovedgrupper av sovemedisiner: benzodiazepiner og benzodiazepinliknende preparater (zopi- klone, zolpidem). Benzodiazepinliknende preparater har færre ulemper og bivirkninger enn benzodiazepiner, ikke minst hos eldre (3), og bør derfor foretrekkes, hvis det er indikasjon for medikamentell behandling. Ved kronisk insomni bør hypnotika unngås. Norske data viser imidlertid at om lag hver femte 80 -åring bruker zopiklone regelmessig (19), og nye tall fra Reseptregisteret i 2011 peker på at 25\% av 80-åringene har hentet ut en resept på zopiklone.

Når det gjelder andre preparater som foreskrives ved søvnvansker (antidepressiver, antihistaminer og nevroleptika) er dokumentasjonen på effekt langt dårligere eller helt fraværende, samtidig som slike medikamenter ofte gir uheldige bivirkninger som tretthet og sløvhet neste dag. Disse medikamentene bør derfor ikke brukes til behandling av søvnvansker, hvis ikke det foreligger spesifikke grunner, som for eksempel komorbid depresjon, nattlig kløe eller psykotiske trekk.

Hvis legen velger å skrive ut sovemedisiner bør intermitterende behandling tilstrebes, for eksempel å benytte sovemedisin annenhver kveld. Ved valg av hypnotikum er det viktig å se på hvilket problem pasienten har. Hvis problemet er tidlig oppvåkning om morgenen, er det nødvendig å velge et preparat som har tilstrekkelig lang virketid. Et sovemiddel med kort virketid er da lite egnet. Ved all medikamentell søvnbehandling, ikke minst hos eldre, bør man som hovedregel benytte lavest mulig effektive dose i kortest mulig tid. Ved langvarig bruk av sovemedisiner bør man forsøke å redusere eller gradvis seponere preparatet. Undersøkelser både fra sykehjem og fra norsk allmennpraksis viser at dette er gjennomførbart i praksis $(20,21)$.

Mye forventning har knyttet seg til melatonins rolle $i$ behandlingen av insomni hos eldre. Melatonin har en veldokumentert virkning på døgnrytmeforstyrrelser, mens virkningen som en ren sovemedisin har vært mer usikker. Et depotpreparat av melatonin (Circadin ${ }^{\circledR}$ ) ble i 2008 godkjent i Norge med indikasjonen insomni hos pasienter som er 55 år eller eldre. Preparatet er vist å gi kortere innsovningstid og bedre subjektiv søvnkvalitet (22). Men det finnes ikke sammenliknende studier mellom depotmelatonin og andre hypnotika eller CBTi. Hos demente pasienter har melatonin ikke vist seg å ha effekt som sovemedisin, verken i sin vanlige form eller som depotpreparat (23). En stor fordel med melatoninpreparatene er at disse ikke er vanedannende og effekten ser ut til å holde seg over tid. Langtidsbruk bør imidlertid kun gis etter grundig vurdering.

\section{DØGNRYTMEFORSTYRRELSER}

Døgnrytmen endres med årene $(1,2)$. Mange eldre opplever at både oppvåkning om morgenen og søvntrang om kvelden kommer tidligere enn før. Dette skyldes endret funksjon av den biologiske klokken, lokalisert i nucleus suprachiasmaticus. Lysbehandling er regnet som den mest effektive behandlingen av døgnrytmeforstyrrelser (24). Kunstig lysbehandling i om lag 30 


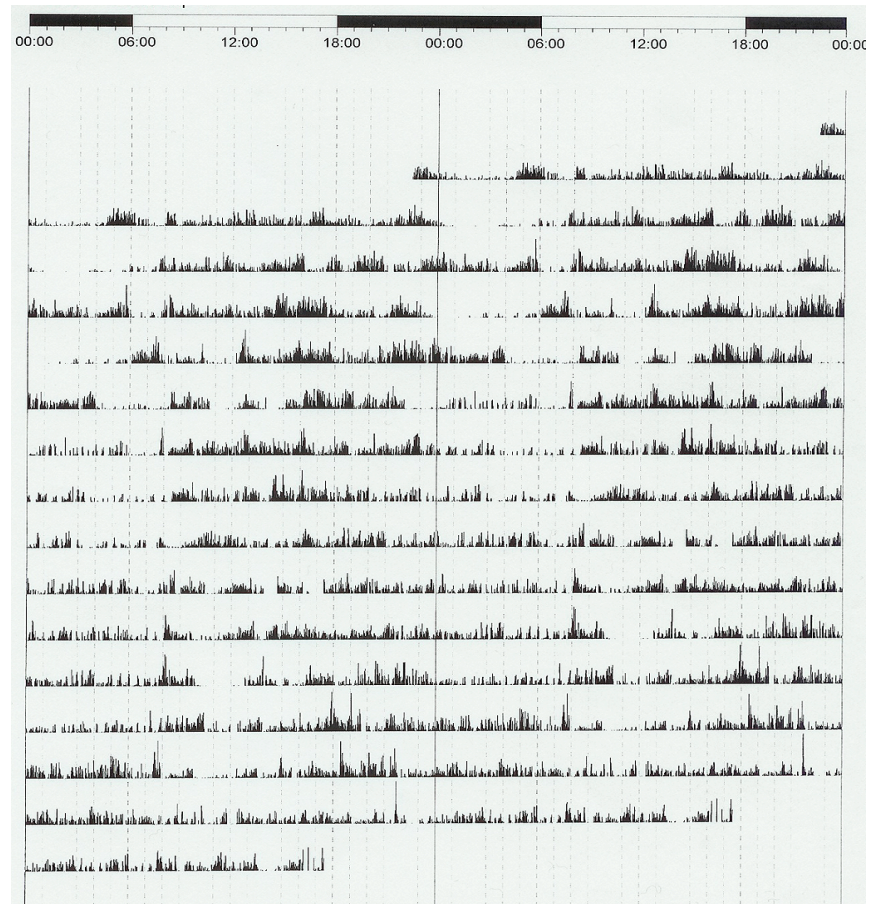

Figur 2. Aktigrafisk registrering av en pasient med alvorlig demens. Vertikale streker indikerer aktivitet og våkenhet. Legg merke til manglende rytme i søvn og våkenhet, noe som tyder på irregulær søvn-våkenhetsrytme. Søvnen er veldig fragmentert og det sees mange våkenperioder om natten (figuren er hentet fra boken "Søvnsykdommer" av Bjørn Bjorvatn, Fagbokforlaget, 2012).

minutter daglig med hvitt lys med intensitet på 10000 lux kan benyttes ved manglende dagslys. Lyseksponering gitt før sengetid forskyver døgnrytmen til et senere tidspunkt, med det resultat at man sover lenger om morgenen. Lys gitt like etter oppvåkning skyver døgnrytmen den andre veien, og vil kunne gjøre at man våkner tidligere neste dag. Det riktige tidspunktet for lyseksponeringen er derfor avhengig av hvilken døgnrytmeforstyrrelse pasienten har.

Hos eldre er fremskyndet søvnfasesyndrom og irregulær søvn-våkenhetsrytme de vanligste døgnrytmeforstyrrelsene. Ved fremskyndet søvnfasesyndrom er hele søvnfasen forskjøvet til et tidligere tidspunkt på døgnet enn normalt. Dette medfører behov for å legge seg tidlig om kvelden, for eksempel rundt klokken 21. Søvnen er av normal lengde og kvalitet, noe som betyr at pasienten våkner opp tidlig om morgenen. Årsaken synes å være at den biologiske klokken følger en rytme på mindre enn 24 timer. Pasienter med fremskyndet søvnfasesyndrom er det vil kaller ekstreme Amennesker. Det finnes få studier på forekomst av slike plager, noe som betyr at det er uklart hvor mange som sliter. Arvelige faktorer spiller inn, og det er påvist visse gener som gir økt sårbarhet for fremskyndet søvnfasesyndrom.

Ved fremskyndet søvnfasesyndrom anbefales lysbehandling rett før sengetid (24). Dette vil kunne forsinke innsovningstidspunktet, og gjøre at pasienten sover lenger om morgenen. Eksponeringstidspunktet for lys kan forskyves fra kveld til kveld inntil ønsket plassering av søvnfasen er oppnådd. Klinisk erfaring og enkelte forskningsstudier peker på gunstig effekt av lys- behandling hos pasienter med fremskyndet søvnfasesyndrom. Men ikke alle pasienter responderer like godt. Hvis effekten mangler eller er lite tilfredsstillende etter 2-3 uker med behandling er det liten grunn til å fortsette.

Irregulær søvn-våkenhetsrytme er karakterisert av manglende døgnrytme i søvn og våkenhet. Søvn og våkenhet sees $\mathrm{i}$ varierende lengder gjennom hele døgnet (figur 2). I de mest alvorlige tilfellene er søvnen svært fragmentert, hvor det ikke sees én sammenhengende time med søvn eller våkenhet i løpet av døgnets 24 timer (6). Hovedsymptomene er kroniske søvnproblemer og økt søvnighet. Forekomsten av denne døgnrytmeforstyrrelsen er ukjent, men tilstanden er ofte assosiert til nevrologisk skade. Diagnosen sees hyppigst hos demente pasienter som er inneliggende på institusjon. Mye tyder på at selve døgnrytmeklokken kan være skadet hos en del av pasientene. Det er tap av hjerneceller i nucleus suprachiasmaticus med økende alder. Det antas videre at døgnrytmeforstyrrelsen kan utløses av dårlig søvnhygiene eller hvis pasienten ikke eksponeres i tilstrekkelig grad for tidgivere, som dagslys. Dette kan være en av forklaringene på at institusjonaliserte pasienter oftere har slike plager.

Målsetningen med behandling av irregulær søvnvåkenhetsrytme er å øke styrken på døgnrytmen, det vil si å skape et større skille mellom dag og natt. Lysbehandling har vist seg å gi bedre søvn om natten og mer våkenhet på dagtid. Flest studier har vært gjort blant demente pasienter. Effekten kan være svært god. Ofte gis lysbehandlingen om morgenen. I en norsk undersøkelse (25) plasserte vi lyskasser foran demente 
Tabell 3. Lysbehandling av demente pasienter på sykehjem. Søvnen ble registrert objektivt med aktigrafer tre separate ganger. "Baseline" viser at pasientene i gjennomsnitt var våkne rundt 3,5 timer i løpet av søvnperioden. Kolonnen "Før beh." viser resultatene fra undersøkelsen hvor pasientene har lyskassene foran seg på frokostbordet, men lyset er ikke skrudd på. Pasientene ligger omtrent like lenge våken som under "baseline". Kolonnen "Etter beh." viser resultatene av to ukers lysbehandling. Tiden med våkenhet om natten var redusert til 1 time og 40 minutter. Lysbehandlingen forbedret også de andre søvnparametrene. Kolonnen "p" viser signifikansnivåene.

\begin{tabular}{llrrrc}
\hline & & \multicolumn{1}{c}{ Baseline } & Før beh. & Etter beh. & $p$ \\
\cline { 3 - 5 } Total tid våken & (time:min) & $3: 33 \pm 1: 20$ & $3: 24 \pm 2: 04$ & $1: 40 \pm 1: 12$ & .003 \\
\hline Innsovningstid & (time:min) & $0: 48 \pm 0: 35$ & $1: 17 \pm 1: 08$ & $0: 17 \pm 0: 17$ & .011 \\
Våkenhet om natten & (time:min) & $2: 32 \pm 1: 11$ & $1: 49 \pm 1: 07$ & $1: 23 \pm 1: 03$ & .037 \\
Våkenhet om morgenen & (time:min) & $0: 10 \pm 0: 09$ & $0: 16 \pm 0: 18$ & $0: 01 \pm 0.02$ & .027 \\
Total søvnlengde & (time:min) & $9: 19 \pm 1: 28$ & $9: 10 \pm 2: 11$ & $10: 12 \pm 1: 36$ & .076 \\
Tid i sengen & (time:min) & $12: 47 \pm 2: 46$ & $12: 32 \pm 1: 16$ & $11: 56 \pm 1: 28$ & .015 \\
Søvneffektivitet & $(\%)$ & $72.9 \pm 8.1$ & $72.9 \pm 16.0$ & $85.6 \pm 9.5$ & .006 \\
\hline
\end{tabular}

pasienter mens de spiste frokost, og etter to ukers behandling ble våkenperiodene om natten redusert med nesten to timer (se tabell 3). Alle beboerne fikk forbedret søvn, men i varierende grad. Nærmest ingen bivirkninger ble registrert. Etter avsluttet lysbehandling ble søvnen registrert regelmessig over flere måneder. Etter 3-4 måneder var søvnen tilbake til slik den var før lysbehandlingen (25). Regelmessig lysbehandling er derfor nødvendig.

I tillegg til lysbehandling anbefales økt sosial og fysisk aktivitet på dagtid. Dette vil kunne styrke forskjellen mellom dag og natt. Mange eldre på institusjoner småsover flere ganger i løpet av dagen, noe som svekker oppbygging av søvnbehovet (homeostatisk faktor).

\section{SØVNRELATERTE RESPIRASJONS- FORSTYRRELSER}

Søvnrelaterte respirasjonsforstyrrelser karakteriseres av unormalt pustemønster under søvn. Ved obstruktiv søvnapne er det en obstruksjon i luftveiene, noe som gir dårlig ventilasjon. De øvre luftveiene klapper sammen, spesielt de bløteste strukturene i svelget. Dette kan medføre at oksygeninnholdet i blodet synker, pulsen stiger og kroppen settes i alarmberedskap. Dette gjør at muskelaktiviteten for å få sugd nok luft ned i lungene øker. Dette ledsages ofte av kortvarige oppvåkninger og snorkelyder.

Snorking forekommer hos mer enn $50 \%$ av voksne mennesker. Mange menn begynner å snorke i ungdommen, mens de fleste kvinner først begynner $\mathrm{i}$ overgangsalderen. Snorking er et vanlig symptom på obstruktiv søvnapne, men ikke alle pasienter med obstruktiv søvnapne snorker. Andre vanlige tegn på obstruktiv søvnapne er pustepauser under søvn (observert av sengepartner) og økt tretthet/søvnighet om dagen. Pasientene er ofte slitne om morgenen, og noen forteller at de er trettere etter nattesøvnen enn det de var før de la seg om kvelden. Morgenhodepine og munntørrhet er også vanlig. Snorkingen er ofte mest plagsom for omgivelsene, og av og til er snorkingen så høy at det er umulig å dele seng med pasienten. Puste- pausene under søvn kan være svært skremmende for sengepartneren. Pustepausene klassifiseres i fullstendig opphør (apne) eller partiell opphør (hypopne) av luftstrømningen gjennom nese og munn. Av diagnostiske hensyn må pustepausene vare minst 10 sekunder om gangen for at de skal regnes som apneer/hypopneer under søvn. Noen pasienter har opp til 100 slike pustepauser i timen. Hos enkelte kan pustepausene vare opp til over et minutt av gangen, men de fleste er mellom 10 og 30 sekunder. Pustepausene kan opptre i alle søvnstadier, men er vanligere i lett søvn og REM-søvn enn i dyp søvn. I REM-søvn er ofte pustepausene lengre og gir større fall i oksygenmetningen.

Forekomsten av søvnrelaterte respirasjonsforstyrrelser øker med økende alder. Dette kan skyldes mange faktorer, blant annet redusert tonus i svelgmuskulaturen jo eldre man blir. Men det er spesielt overvekt som er assosiert til økt forekomst av søvnapne. Det er anslått at flertallet av eldre over 60 år kan ha søvnrelaterte respirasjonsforstyrrelser, hyppigere hos menn og ved høyt blodtrykk (26). Mange med slike respirasjonsforstyrrelser har ikke fått korrekt diagnose eller behandling. Obstruktiv søvnapne regnes som en risikofaktor for blant annet kardiovaskulære lidelser og økt dødelighet (27).

Diagnosen obstruktiv søvnapne stilles etter objektiv registrering av respirasjonen under søvn. Det vil si at diagnosen ikke kan stilles utelukkende basert på subjektive plager som høylytt snorking, pustepauser under søvn og tretthet på dagtid. Ved mistanke om en søvnrelatert respirasjonsforstyrrelse bør pasienten henvises til spesialavdelinger, uavhengig av alder. Det er stor helsegevinst i korrekt håndtering av slike lidelser.

Alle pasienter med obstruktiv søvnapnesyndrom bør tilbys konservativ behandling, enten alene eller sammen med annen behandling. Konservativ behandling $\mathrm{i}$ form av livsstilsendringer som røykeslutt og vektreduksjon er veldig viktig. Fedme er den viktigste årsaken til søvnapne, og vektreduksjon reduserer søvnapneplagene. Sideleie vil hos mange pasienter gi reduksjon av apnetendensen, mens ryggleie har motsatt effekt. Hevet hodeende kan hos noen være nyttig. Røyking er vist å gi økt sannsynlighet for søvnapne- 
syndrom og røykeslutt reduserer plagene hos mange pasienter. Allergi med symptomer som nesetetthet og hevelse av slimhinnene $\mathrm{i}$ halsen vil bidra til økt tendens til søvnapne. Effektiv allergibehandling vil kunne redusere forandringene av slimhinnene, redusere sliming og gi bedre romforhold i nese og hals. Alkohol og enkelte medikamenter (benzodiazepiner) kan gi forverring av søvnapne, og bør unngås.

Ved moderat til alvorlig grad av søvnapne er kontinuerlig overtrykksbehandling (CPAP) regnet som førstevalget (28). Effekten av slik behandling er svært god, men en del pasienter sliter med å tolerere utstyret. Behandlingsalternativer er snorkeskinne eller kirurgiske inngrep i nese eller svelg.

En annen mer sjelden form for søvnrelatert respirasjonsforstyrrelse er sentral søvnapne. Ved sentral søvnapne mangler den normale pusteanstrengelsen, og ventilasjonen er dårlig selv om det ikke foreligger obstruksjon av luftveiene. Her fungerer ikke signalene mellom hjernens åndedrettssentrum og pustemuskulaturen. Sentral søvnapne sees oftest hos eldre mennesker, ved hjertesvikt eller etter hjerneslag, og har sammenheng med skader i hjernen eller nervebanene. Flere typer behandling kan være aktuelt, blant annet medikamenter, ventilasjonstøtte via maske og oksygentilførsel. Enkelte pasienter har en blanding av obstruktiv og sentral søvnapne.

\section{SØVNRELATERTE BEVEGELSES- FORSTYRRELSER}

Søvnrelaterte bevegelsesforstyrrelser består av en gruppe lidelser som kjennetegnes av relativt enkle og stereotype bevegelser som forstyrrer søvnen. Mest kjent er restless legs syndrom (RLS) og periodiske beinbevegelser under søvn (PLMS).

Restless legs syndrom (også kalt urolige eller rastløse bein) er en nevrologisk lidelse. Diagnosen stilles utelukkende basert på pasientens anamnese, det vil si at det ikke er objektive diagnosekriterier (1). Pasienten klager over kriblende fornemmelser i beina som ledsages av en trang til bevegelse. Ubehaget lindres helt eller delvis av bevegelse, og symptomene oppstår derfor i hvile eller ved inaktivitet. Symptomene viser en tydelig døgnvariasjon, med plager spesielt om kveld og natt. Diagnosen er lett å stille. Likevel forblir restless legs syndrom ofte udiagnostisert og ubehandlet. Dette skyldes at kunnskapen om restless legs er mangelfull blant helsepersonell. Det blir hevdet at restless legs syndrom er den hyppigste lidelsen ingen kjenner til. Mange pasienter med restless legs klager over innsovningsproblemer eller urolig nattesøvn. Tretthet eller søvnighet på dagtid er også vanlig. I en stor internasjonal epidemiologisk undersøkelse rapporterte $75 \%$ av pasientene minst ett søvnrelatert symptom, mer enn $50 \%$ av pasientene rapporterte dårlig funksjonsnivå på dagtid, og rundt hver tredje pasient rapporterte om økt søvnighet (29).

Obligatoriske kriterier for RLS (alle fire må være til stede):
1. Trang til å bevege beina på grunn av ubehagelige, kriblende fornemmelser.

2. Trangen til å bevege seg eller de ubehagelige fornemmelsene oppstår i hvile eller ved inaktivitet.

3. Symptomene lindres helt eller delvis av bevegelser, for eksempel hvis man går eller strekker seg.

4. Trangen er til stede spesielt om kvelden eller natten, og ikke tidlig på dagen.

Følgende kliniske trekk støtter RLS-diagnosen:

1. Andre i familien med samme plager.

2. God effekt av behandling med dopaminerge medikamenter.

3. Periodiske beinbevegelser under søvn (eller i våken tilstand).

Det er flest kvinner som plages, og hyppigheten øker med alderen. I en skandinavisk spørreundersøkelse fra 2005 tilfredsstilte $12 \%$ av personer $>60$ år kriteriene for denne diagnosen, og omtrent halvparten beskrev plagene som moderate eller alvorlige (30). Tilstanden finnes $i$ en primær og en sekundær form. Den sekundære formen assosieres med tilstander som nyresykdom, jern- og vitaminmangel, graviditet, skader på nervesystemet, revmatiske sykdommer, medisinbruk, alkohol, koffein eller røyk.

\section{Ikke-medikamentell behandling}

Noen pasienter har nytte av regelmessig fysisk aktivitet, for eksempel spaserturer på kveldstid. Massasje av muskulaturen i beina kan også hjelpe. Det er viktig med god søvnhygiene. Alkohol, spesielt visse typer rødvin, kan utløse eller forverre restless legs, og bør unngås. Koffein og nikotin kan også utløse eller forverre restless legs.

Hvis det er sannsynlig at restless legs-plagene skyldes bivirkninger av et legemiddel bør medikamentet seponeres eller eventuelt erstattes. Av og til vil endring av doseringstidspunkt være nok til å redusere plagene. Antidepressive medikamenter av typen selektive serotonin-reopptakshemmere er kjent for å kunne gi restless legs, og kan for eksempel flyttes fra kvelds- til morgendosering.

\section{Medikamentell behandling}

Ved alvorlige plager er bruk av medikamenter anbefalt. Jerntilskudd kan ha god effekt, hvis det er tegn på mangel. Det anbefales å gi jerntilskudd ved ferritinnivå under 50 (31). Førstehåndspreparater ved medikamentell behandling av restless legs er dopamin-agonister (32). Effekten er ofte så god at ved manglende effekt bør diagnosen revurderes. I Norge er to dopaminagonister (pramipeksol, ropinirol) registrert til behandling av restless legs syndrom. Behandlingseffekten er like god for begge preparatene. Det benyttes lave doser, og av den grunn sees få bivirkninger. Kvalme og gastrointestinale bivirkninger er de vanligste. En alvorlig bivirkning ved langvarig bruk av dopaminerge preparater er augmentasjon, det vil si at plagene blir verre enn de var før behandlingen ble startet. Dette er en paradoksal reaksjon, hvor pasientene gjerne får 
symptomer tidligere på dagen, eventuelt en spredning av plagene til andre ekstremiteter (armene) eller mer kortvarig lindring av det dopaminerge preparatet. Alternativer til dopamin-agonister er gabapentin, kodein, tramadol og klonazepam.

Periodiske beinbevegelser under søvn (PLMS) er en annen vanlig søvnrelatert bevegelsesforstyrrelse, som ofte er assosiert til restless legs (33). Diagnosen PLMS kan kun stilles etter polysomnografi, hvor det sees gjentatte, stereotype beinbevegelser mens pasienten sover. Slike rykninger i beina under søvn kan gi hyppige oppvåkninger og tretthet på dagtid. Mange eldre har PLMS, og det har vært stilt spørsmål rundt validiteten av denne diagnosen. Grunnen til det er blant annet at enkelte personer kan ha høy PLM-indeks uten å klage over søvnproblemer eller tretthet på dagtid. Den kliniske betydningen av beinbevegelser under søvn uten andre symptomer er usikker. Behandlingen av PLMS er den samme som for restless legs syndrom.

\section{HYPERSOMNIER}

Hypersomnier er sjeldne lidelser, som kjennetegnes av ekstrem søvnighet og/eller søvnbehov. Den mest kjente av disse er narkolepsi som er en alvorlig nevrologisk lidelse. De typiske symptomene ved narkolepsi er ekstrem søvnighet, anfall med tap av muskelspenning (katapleksi), livlige drømmer under innsovning (hypnagoge hallusinasjoner) og søvnparalyse (34). Det går vanligvis flere år fra symptomene melder seg til lidelsen blir diagnostisert. Selv om hypersomniene kan oppstå i alle aldre starter vanligvis slike plager i ung alder. De fleste hypersomniene varer livet ut, og eldre vil derfor også ha slike plager, selv om det er uvanlig at diagnosen først stilles $\mathrm{i}$ høy alder.

Alvorlig hypersomni behandles vanligvis ved hjelp av våkenstimulerende medikamenter. Mest brukt er modafinil og ulike amfetamin-preparater. Oppstart av slik behandling regnes som spesialistoppgave.

\section{Parasomnier}

Parasomnier defineres som uønsket atferd eller ubehagelige fenomener under søvn og inkluderer blant annet søvngjengeri og marerittlidelse. De fleste parasomniene er vanligst hos barn, men en av parasomniene sees spesielt hos eldre, nemlig REM-søvn atferdsforstyrrelse. Dette er en sjelden, men svært alvorlig søvnforstyrrelse. Lidelsen karakteriseres av ekstremt livlige drømmer, hvor den normale REM-søvn-tilknyttede muskellammelsen uteblir (35). Pasienten kan derfor delta aktivt i drømmen med voldsom motorisk aktivitet. Pasienten kan for eksempel drømme at han selv eller hans nærmeste blir angrepet, og at han slåss for å forsvare seg. I virkeligheten går han til angrep på sengepartneren. REM-søvn atferdsforstyrrelse sees hyppigst hos menn over 60 år, og er assosiert til ulike nevrodegenerative lidelser som Parkinsons sykdom og demens. REM-søvn atferdsforstyrrelse kan være et tidlig tegn på at en nevrodegenerativ lidelse er under utvikling. En slik forstyrrelse kan også sees i abstinensfaser etter alkohol eller sentralstimulerende legemidler. Enkelte medikamenter, og da spesielt antidepressive medikamenter, har vært vist å kunne utløse REM-søvn atferdsforstyrrelse. Forekomsten av REMsøvn atferdsforstyrrelse er sjelden, sannsynligvis < $1 \%$. Helsepersonell bør få mistanke om denne forstyrrelsen hvis en pasient forteller om å leve ut drømmene i søvne. Pasienten bør da henvises til sykehus/søvnsenter. Dette er den eneste parasomnien som krever polysomnografisk undersøkelse for å bli diagnostisert. Behandlingen er medikamentell, og klonazepam er vist å ha svært god effekt.

\section{KONKLUSJON}

Mange av de ulike søvnforstyrrelsene er vanligere blant eldre enn blant yngre personer. Men det betyr ikke at søvnforstyrrelsene nødvendigvis er en naturlig konsekvens av alderdom. Redusert evne til å sovne og til å sove sammenhengende natten gjennom påvirkes av en rekke faktorer, både psykiske og fysiske. For å kunne diagnostisere og behandle søvnforstyrrelser hos eldre kreves det god kjennskap til pasientens sykehistorie og medisinbruk, og pasientens søvnmønster kan registreres med søvndagbok. Behandlingsalternativene varierer fra ikke-medikamentelle til medikamentelle tiltak, avhengig av diagnosen.

\section{REFERANSER}

1. Bjorvatn B. Søvnsykdommer. Moderne utredning og behandling. Bergen: Fagbokforlaget, 2012.

2. Wolkove N, Elkholy O, Baltzan M, Palayew M. Sleep and aging: 1. Sleep disorders commonly found in older people. CMAJ 2007; 176 (9): 1299-304.

3. Wolkove N, Elkholy O, Baltzan M, Palayew M. Sleep and aging: 2. Management of sleep disorders in older people. CMAJ 2007; 176 (10): 1449-54.

4. Sack RL, Auckley D, Auger RR, Carskadon MA, Wright KP, Jr, Vitiello MV, et al. Circadian rhythm sleep disorders: part I, basic principles, shift work and jet lag disorders. An American Academy of Sleep Medicine review. Sleep 2007; 30 (11): 1460-83.

5. Crowley K. Sleep and sleep disorders in older adults. Neuropsychol Rev 2011; 21 (1): 41-53.

6. Jacobs D, Ancoli-Israel S, Parker L, Kripke DF. Twenty-four-hour sleep-wake patterns in a nursing home population. Psychol Aging 1989; 4 (3): 352-6. 
7. Fetveit A, Bjorvatn B. Sleep disturbances among nursing home residents. Int J Geriatr Psychiatry 2002; 17 (7): 604-9.

8. Fetveit A, Bjorvatn B. Søvnforstyrrelser hos sykehjemspasienter - praktiske behandlingsråd. Tidsskr Nor Laegeforen 2005; 125 (12): 1676-8.

9. American Academy of Sleep Medicine. International classification of sleep disorders, 2nd ed.: Diagnostic and coding manual. Westchester, IL, 2005.

10. Sivertsen B, Krokstad S, Overland S, Mykletun A. The epidemiology of insomnia: associations with physical and mental health. The HUNT-2 study. J Psychosom Res 2009; 67 (2): 109-16.

11. Stepanski EJ, Rybarczyk B. Emerging research on the treatment and etiology of secondary or comorbid insomnia. Sleep Med Rev 2006; 10 (1): 7-18.

12. Buscemi N, Vandermeer B, Friesen C, Bialy L, Tubman M, Ospina M, et al. The efficacy and safety of drug treatments for chronic insomnia in adults: a meta-analysis of RCTs. J Gen Intern Med 2007; 22 (9): 1335-50.

13. Kripke DF. Chronic hypnotic use: deadly risks, doubtful benefit. Sleep Med Rev 2000; 4 (1): 5-20.

14. Sivertsen B, Omvik S, Pallesen S, Bjorvatn B, Havik OE, Kvale G, et al. Cognitive behavioral therapy vs zopiclone for treatment of chronic primary insomnia in older adults: a randomized controlled trial. JAMA 2006; 295 (24): 2851-8.

15. Wilson SJ, Nutt DJ, Alford C, Argyropoulos SV, Baldwin DS, Bateson AN, et al. British Association for Psychopharmacology consensus statement on evidence-based treatment of insomnia, parasomnias and circadian rhythm disorders. $J$ Psychopharmacol 2010; 24 (11): 1577-601.

16. Kripke DF, Klauber MR, Wingard DL, Fell RL, Assmus JD, Garfinkel L. Mortality hazard associated with prescription hypnotics. Biol Psychiatry 1998; 43 (9): 687-93.

17. Bjorvatn B, Sivertsen B, Øyane N, Nordhus IH, Pallesen S. Insomni. Tidsskr Nor Legeforen 2009; 129 (17): $1766-8$.

18. Morin CM, Culbert JP, Schwartz SM. Nonpharmacological interventions for insomnia: a meta-analysis of treatment efficacy. Am J Psychiatry 1994; 151 (8): 1172-80.

19. Mellingsæter TC, Bramness JG, Slørdal L. Er z-hypnotika bedre og tryggere sovemedisiner enn benzodiazepiner? Tidsskr Nor Laegeforen 2006; 126 (22): 2954-6.

20. Poyares D, Guilleminault C, Ohayon MM, Tufik S. Chronic benzodiazepine usage and withdrawal in insomnia patients. $J$ Psychiatr Res 2004; 38 (3): 327-34.

21. Mouland G. Brev til brukere av benzodiazepiner - en effektiv måte å få ned forskrivingen på. Tidsskr Nor Lageforen 1997; 117 (21): 3097-100.

22. Wade AG, Ford I, Crawford G, McMahon AD, Nir T, Laudon M, et al. Efficacy of prolonged release melatonin in insomnia patients aged 55-80 years: quality of sleep and next-day alertness outcomes. Curr Med Res Opin 2007; 23 (10): 2597-605.

23. Singer C, Tractenberg RE, Kaye J, Schafer K, Gamst A, Grundman M, et al. A multicenter, placebocontrolled trial of melatonin for sleep disturbance in Alzheimer's disease. Sleep 2003; 26 (7): 893-901.

24. Bjorvatn B, Pallesen S. A practical approach to circadian rhythm sleep disorders. Sleep Med Rev 2009; 13 (1): 47-60.

25. Fetveit A, Bjorvatn B. The effects of bright-light therapy on actigraphical measured sleep last for several weeks post-treatment. A study in a nursing home population. J Sleep Res 2004; 13 (2): 153-8.

26. Tishler PV, Larkin EK, Schluchter MD, Redline S. Incidence of sleep-disordered breathing in an urban adult population: the relative importance of risk factors in the development of sleep-disordered breathing. JAMA 2003; 289 (17): 2230-7.

27. Ocasio-Tascon ME, Alicea-Colon E, Torres-Palacios A, Rodriguez-Cintron W. The veteran population: one at high risk for sleep-disordered breathing. Sleep Breath 2006; 10 (2): 70-5.

28. Akre H, Øverland B, Skatvedt O. Respirasjonsforstyrrelser under søvn. Tidsskr Nor Legeforen 2009; 129 (17): 1762-5.

29. Allen RP, Walters AS, Montplaisir J, Hening W, Myers A, Bell TJ, et al. Restless legs syndrome prevalence and impact: REST general population study. Arch Intern Med 2005; 165 (11): 1286-92.

30. Bjorvatn B, Leissner L, Ulfberg J, Gyring J, Karlsborg M, Regeur L, et al. Prevalence, severity and risk factors of restless legs syndrome in the general adult population in two Scandinavian countries. Sleep Med 2005; 6 (4): $307-12$.

31. Wang J, O'Reilly B, Venkataraman R, Mysliwiec V, Mysliwiec A. Efficacy of oral iron in patients with restless legs syndrome and a low-normal ferritin: A randomized, double-blind, placebo-controlled study. Sleep Med 2009; 10 (9): 973-5.

32. Kinge E, Ulfberg J. Søvnrelaterte bevegelsesforstyrrelser. Tidsskr Nor Legeforen 2009; 129 (18): 1888-91.

33. Bjorvatn B, Holsten F, Skeidsvoll H. Periodiske benbevegelser under søvn - kan og skal de behandles? Tidsskr Nor Laegeforen 2001; 121 (18): 2169-72.

34. Sand T, Schrader H. Narkolepsi og andre hypersomnier. Tidsskr Nor Legeforen 2009; 129 (19): 2007-10.

35. Mahowald MW, Schenck CH. Insights from studying human sleep disorders. Nature 2005; 437 (7063): 127985. 